\title{
BJUI Comment
}

\section{Novel agents for metastatic hormone-sensitive prostate cancer - A practice guide for urologists}

Thangasamy $\mid \mathrm{A}^{1,2}$, Kwan $\mathrm{EM}^{3,4}$, Teh J1 , Sathianathen $\mathrm{N}^{1}$, Alghazo $\mathrm{O}^{1}$, Siva $\mathrm{S}^{5,6}$, Azad $\mathrm{A}^{4,6}$, Murphy DG ${ }^{1,6}$

1. Division of Cancer Surgery, Peter MacCallum Cancer Centre, Melbourne, Australia

2. Faculty of Medicine, University of Queensland, Brisbane, Australia

3. Department of Medicine, School of Clinical Sciences, Monash University, Australia

4. Department of Medical Oncology, Monash Health, Australia

5. Division of Radiation Oncology, Peter MacCallum Cancer Centre, Melbourne, Australia

6. Sir Peter MacCallum Department of Oncology, University of Melbourne, Parkville, Australia

Corresponding author:

Professor Declan G Murphy

Peter MacCallum Cancer Centre

305 Grattan Street,

Parkville, 3000

Victoria,

Australia

E: declan.murphy@petermac.org

Keywords: prostate cancer, chemotherapy, metastasis, hormone sensitive, androgen axis targeted therapies

This is the author manuscript accepted for publication and has undergone full peer review but has not been through the copyediting, typesetting, pagination and proofreading process, which may lead to differences between this version and the Version of Record. Please cite this article as doi: $10.1111 /$ BJU.14936

This article is protected by copyright. All rights reserved 
Word count: 950
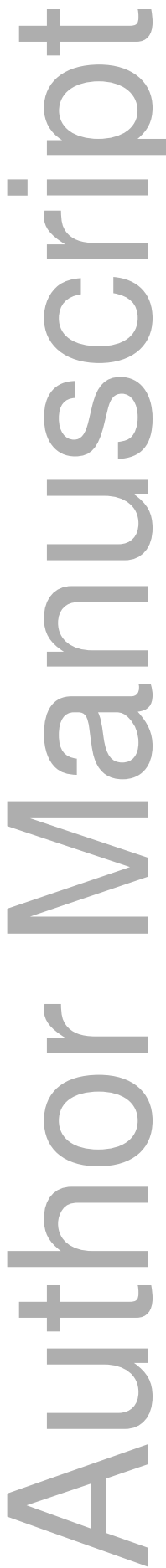

This article is protected by copyright. All rights reserved 
DR. ISAAC A THANGASAMY (Orcid ID : 0000-0003-1820-6114)

DR. EDMOND KWAN (Orcid ID : 0000-0002-7053-680X)

DR. DECLAN MURPHY (Orcid ID : 0000-0002-7500-5899)

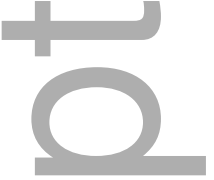

Article type : Comment

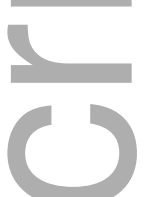

The last five years has witnessed a remarkable evolution in the management of metastatic hormone-sensitive prostate cancer (mHSPC), with multiple agents demonstrating profound benefit in combination with initial androgen deprivation therapy (ADT). Historically, in a time when systemic therapy options were scarce, the responsibility of monitoring ADT efficacy fell squarely on urologists. As the disease progressed inevitably to the castrationresistant state, primary care would transition to medical oncologists, with urologists limited to providing interventional support for local complications on an as needed basis.

Pivotal data from the landmark CHAARTED [1] and STAMPEDE [2] trials has subsequently altered this dynamic, establishing the role of upfront docetaxel as a new standard of care for $\mathrm{mHSPC}$, especially in patients with high-volume disease. Thus, urologists appropriately relinquished the management of eligible patients to their medical oncology colleagues - a paradigm shift away from urologists as the principal custodians of $\mathrm{mHSPC}$.

Concurrently, novel androgen axis (AA) targeting agents began to be studied in the mHSPC disease state, based on the hypothesis that potent upfront AA inhibition (when androgen dependent tumour clones predominate) would result in improved survival outcomes and quality of life, while simultaneously delaying the requirement for cytotoxic chemotherapy, which has a far less favourable toxicity profile.

Importantly, these novel AA targeting agents are oral agents, with a good safety profile and well described monitoring requirements. Therefore, it stands to reason, that urologists may once again become the principal custodians of $\mathrm{mHSPC}$, rather than refer these patients onto 
already over-burdened medical oncologists. However, urologists must become familiar with the indications, mode of action, adverse events, and monitoring requirements associated with novel AA targeting agents if they are to use them for mHSPC patients in practice. Table 1 outlines the key practice points of these novel agents with proven efficacy data, including monitoring and management of adverse events.

Abiraterone is a selective and irreversible steroidal inhibitor of CYP17A1, a key enzyme in the androgen biosynthesis pathway. Meta-analysis of the STAMPEDE and LATITUDE trials studying Abiraterone showed that Abiraterone combined with prednisone and ADT resulted in a $38 \%$ reduction in risk of death ( $\mathrm{HR} 0.62 ; 95 \% \mathrm{Cl} 0.53-0.71)$ and a $14 \%$ increase in OS at 3 years compared with ADT alone [3]. Abiraterone is associated with a two-fold increase in hypertension and a three-fold increase in cardiac and hepatic toxicity compared with ADT monotherapy [3]. Hence it should be avoided in men with uncontrolled hypertension, cardiac failure, pre-existing liver disease and poorly controlled diabetes due to use of concomitant prednisone. With this combination, prednisone serves primarily to counter side effects from mineralocorticoid excess (hypertension, fluid retention and hypokalemia), rather than as a disease modifying agent.

Enzalutamide is a second-generation antiandrogen with multiple mechanisms of action, including inhibition of AR-testosterone ligand binding, AR nuclear translocation and DNA transactivation. The ARCHES [4] and ENZAMET [5] trials recently reported the therapeutic benefits of enzalutamide combined with ADT compared with ADT alone and ADT plus a nonsteroidal antiandrogen respectively. There was a $61 \%$ delay to radiographic progression of disease or death (HR 0.39; 95\% Cl 0.3-0.5) regardless of disease volume or prior docetaxel treatment [4] and a 33\% improvement in OS (HR 0.67; 95\% Cl 0.52-0.86) [5]. Enzalutamide is associated with a low but significant risk of seizures. Furthermore, clinically significant fatigue and cognition issues are well-recognised and reported in $25 \%$ and $14 \%$ of patients respectively [5]. This point of difference compared to other AR pathway inhibitors is likely to be particularly relevant in older patients.

Lastly, apalutamide is a non-steroidal selective AR antagonist. The TITAN trial reported that apalutamide combined with ADT reduced the risk of radiographic progression by $52 \%$ (HR 
$0.48 ; 95 \% \mathrm{Cl} 0.39-0.60$ ) and risk of death by $33 \%$ (HR 0.67; 95\% Cl 0.51-0.89) [6]. Distinct adverse reactions specific to apalutamide include rash (typically macular/maculopapular in appearance) and hypothyroidism. Apalutamide was also associated with increased ischaemic heart disease compared to placebo (4.4\% vs $1.5 \%)$ [6].

The favourable outcomes seen with these novel AA targeting agents is practice changing. Abiraterone has been incorporated into NCCN/EAU/ESMO guidelines for treatment of mHSPC and it is only a matter of time before the other agents follow suit. In the absence of direct head-to-head comparative trials, selection of appropriate agents will depend heavily on patient comorbidities, side effect profile, local access and reimbursements available. Furthermore, clinical implications of long-term AR inhibition remain unclear, as well as the long-term effects of steroids required with abiraterone acetate use. Research into the impact of sustained androgen deprivation on bone health, tumour biology and optimal sequencing post-progression following use of these new agents remain a high priority. It must be noted that the trials studying novel AA targeting agents mandated the use of continuous background conventional ADT and this is where current evidence is derived from. Regimens that do not include conventional ADT or that utilise intermittent ADT are worth exploring in future trials mainly due to the related long-term toxicity.

In summary, the advent of highly effective and well-tolerated oral agents in the MHSPC space has reshaped the treatment landscape. We believe that urologists can and should reengage in this disease space. Indeed, in some parts of the world, they remain the principal practitioners involved in managing patients across the entire advanced prostate cancer disease spectrum, including the administration of chemotherapy[7]. As the era of ADT monotherapy draws to a close, it is time urologists become familiar with prescribing novel agents. We do not expect urologists to manage all side effects or alter dosages in isolation. However, we propose that it is only through improved understanding and experience with these therapies that urologists can once again significantly contribute to shared decisionmaking alongside their medical oncology colleagues in the multidisciplinary management of patients with advanced prostate cancer. 


\section{Conflicts of interest}

Dr. Azad reports personal fees from Janssen, grants, personal fees, non-financial support and other from Astellas, personal fees from Novartis, grants and non-financial support from Merck Serono, personal fees from Tolmar, personal fees, non-financial support and other from Amgen, personal fees and other from Pfizer, personal fees from Bayer, personal fees and other from Telix Pharmaceuticals, personal fees and other from Bristol-Myers Squibb, personal fees and other from Sanofi, personal fees from Noxopharm, outside the submitted work.

Dr. Kwan reports personal fees from Janssen, grants and personal fees from Astellas Pharma, grants from AstraZeneca, personal fees from Pfizer, personal fees from Ipsen, outside the submitted work.

The remaining authors have nothing to disclose.

\section{References}

1. Sweeney CJ, Chen YH, Carducci M, et al. Chemohormonal Therapy in Metastatic Hormone-Sensitive Prostate Cancer. N Engl J Med. 2015; 373(8): 737-46.

2. James ND, Sydes MR, Clarke NW, et al. Addition of docetaxel, zoledronic acid, or both to first-line long-term hormone therapy in prostate cancer (STAMPEDE): survival results from an adaptive, multiarm, multistage, platform randomised controlled trial. Lancet. 2016; 387(10024): 1163-77.

3. Rydzewska LHM, Burdett $\mathrm{S}$, Vale $\mathrm{CL}$, et al. Adding abiraterone to androgen deprivation therapy in men with metastatic hormone-sensitive prostate cancer: $A$ systematic review and meta-analysis. Eur J Cancer. 2017; 84: 88-101.

4. Armstrong AJ, Szmulewitz RZ, Petrylak DP, et al. Phase III study of androgen deprivation therapy (ADT) with enzalutamide (ENZA) or placebo (PBO) in metastatic 
hormone-sensitive prostate cancer (mHSPC): The ARCHES trial. Journal of Clinical Oncology. 2019; 37(7_suppl): 687-.

5. Davis ID, Martin AJ, Stockler MR, et al. Enzalutamide with Standard First-Line Therapy in Metastatic Prostate Cancer. N Engl J Med. 2019.

6. Chi KN, Agarwal N, Bjartell A, et al. Apalutamide for Metastatic, Castration-Sensitive Prostate Cancer. N Engl J Med. 2019.

7. Chiong $E$, Murphy DG, Akaza $\mathrm{H}$, et al. Management of patients with advanced prostate cancer in the Asia Pacific region: 'real-world' consideration of results from the Advanced Prostate Cancer Consensus Conference (APCCC) 2017. 2019; 123(1): $22-34$.
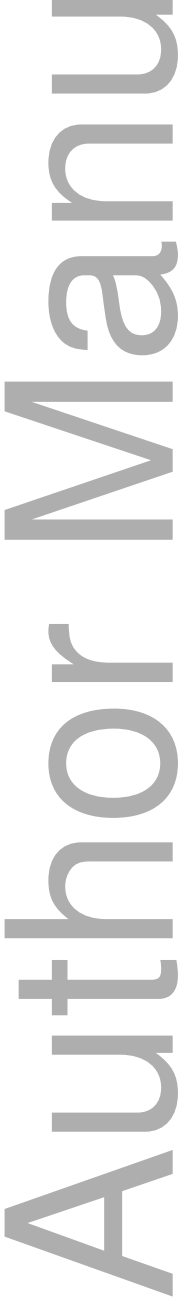
Table 1: Dosage, adverse events and key practice points associated with novel AR pathway inhibitors for mHSPC

\begin{tabular}{|c|c|c|}
\hline Agent and standard dosage & Adverse event & Key practice points \\
\hline \multirow{3}{*}{$\begin{array}{l}\text { Abiraterone } 1000 \mathrm{mg} \text { daily } \\
\text { (4x250mg OR } 2 \times 500 \mathrm{mg} \text { tablets) } \\
\text { prednisone } 5 \mathrm{mg} \text { daily }\end{array}$} & $\begin{array}{l}\text { Cardiovascular disorders } \\
\text { (hypertension, fluid retention, } \\
\text { ischaemic heart disease) }\end{array}$ & $\begin{array}{l}\text { - Timing: most commonly subacute or chronic use; avoid in patients } \\
\text { with } \mathrm{EF}<50 \% \\
\text { - Monitoring: blood pressure } \\
\text { - Management: antihypertensives; refer to cardiologist if any cardiac } \\
\text { symptoms }\end{array}$ \\
\hline & Hypokalemia & $\begin{array}{l}\text { - Timing: typically occurs within first three months of treatment } \\
\text { - Monitoring: at least monthly during initial therapy; extra monitoring in } \\
\text { patients on concurrent non-potassium sparing diuretics (e.g. thiazides) } \\
\text { - Management: potassium replacement therapy }\end{array}$ \\
\hline & $\begin{array}{l}\text { Hyperglycemia } \\
\text { (assoc. with prednisolone) }\end{array}$ & $\begin{array}{l}\text { - Timing: occurs acutely, within days of commencing treatment } \\
\text { - Monitoring: close monitoring of BGLs in patients with brittle diabetes }\end{array}$ \\
\hline
\end{tabular}

This article is protected by copyright. All rights reserved 


\begin{tabular}{|c|c|c|}
\hline r & & $\begin{array}{l}\text { - Management: consider alternate treatment if hyperglycemia cannot } \\
\text { be management pharmacologically; refer to endocrinologist }\end{array}$ \\
\hline \multirow[t]{2}{*}{$\begin{array}{l}\text { Enzalutamide } 160 \mathrm{mg} \text { daily } \\
\text { (4x40mg capsules) }\end{array}$} & Fatigue & $\begin{array}{l}\text { - Timing: variable and common } \\
\text { - Monitoring: conservative monitoring } \\
\text { - Management: consider dose reduction or alternate treatment }\end{array}$ \\
\hline & Seizures & $\begin{array}{l}\text { - Timing: variable } \\
\text { - Monitoring: absolute contraindication in patients with prior seizures; } \\
\text { caution/avoid in skull metastases with dural invasion, medications } \\
\text { that lower seizure threshold (antidepressants, tramadol, sedating } \\
\text { antihistamines, some antipsychotics) and recent stroke } \\
\text { - Management: permanent cessation }\end{array}$ \\
\hline $\begin{array}{l}\text { Apalutamide } 240 \mathrm{mg} \text { daily } \\
\text { (4x60mg tablets) }\end{array}$ & Rash & $\begin{array}{l}\text { - Timing: typically occurs within first three months of therapy } \\
\text { - Monitoring: commonly described as macular/maculopapular in } \\
\text { appearance } \\
\text { - Management: topical corticosteroids, oral antihistamines, systemic } \\
\text { corticosteroids, drug interruption and dose reduction }\end{array}$ \\
\hline
\end{tabular}

This article is protected by copyright. All rights reserved 


\begin{tabular}{|l|l|l|}
\hline & Hypothyroidism & $\begin{array}{l}\bullet \text { Timing: typically occurs within first three months of therapy } \\
- \text { Monitoring: regular review of TFTs during initial treatment phase; } \\
\text { extra monitoring in patients on pre-existing thyroid replacement } \\
\text { therapy } \\
- \text { Management: thyroid replacement therapy; refer to endocrinologist }\end{array}$ \\
\hline
\end{tabular}

$\mathrm{ALT}$ = alanine aminotransferase; $\mathrm{AST}$ = aspartate aminotransferase; $\mathrm{BGL}=$ blood glucose level; $\mathrm{EF}$ = ejection fraction; $\mathrm{LFT}$ = liver function test; TFT = thyroid function test; ULN = upper limit of normal

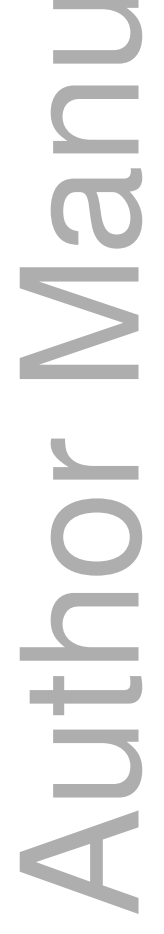

This article is protected by copyright. All rights reserved 


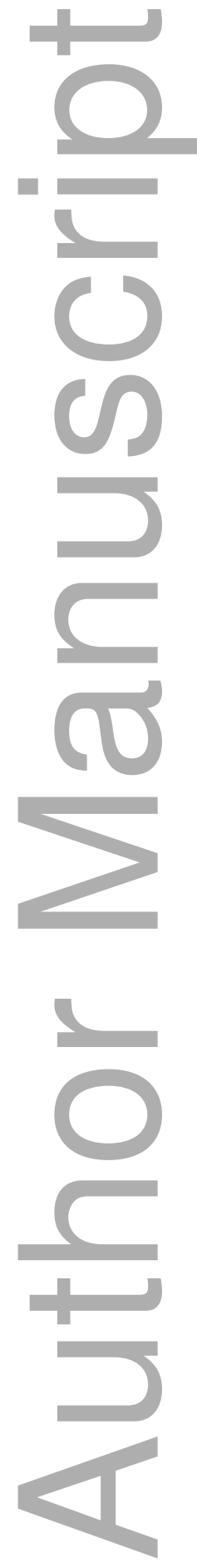

This article is protected by copyright. All rights reserved 


\section{University Library}

\section{- M M N E R VA A gateway to Melbourne's research publications}

Minerva Access is the Institutional Repository of The University of Melbourne

\section{Author/s:}

Thangasamy, IA;Kwan, EM;Teh, J;Sathianathen, N;Alghazo, O;Siva, S;Azad, A;Murphy, DG

Title:

Novel agents for metastatic hormone-sensitive prostate cancer - a practice guide for urologists

\section{Date:}

2019-11-15

\section{Citation:}

Thangasamy, I. A., Kwan, E. M., Teh, J., Sathianathen, N., Alghazo, O., Siva, S., Azad, A. \& Murphy, D. G. (2019). Novel agents for metastatic hormone-sensitive prostate cancer - a practice guide for urologists. BJU INTERNATIONAL, 125 (3), pp.342-345. https:// doi.org/10.1111/bju. 14936.

Persistent Link:

http://hdl.handle.net/11343/286620 